\title{
KWESTIA BOGATYCH POCHÓWKÓW KOBIECYCH W ANTYCZNEJ TRACJI
}

\author{
ON RICH WOMEN BURIALS IN ANCIENT THRACIA
}

\author{
Jerzy Hatlas \\ Biblioteka Uniwersytecka, Uniwersytet im. Adama Mickiewicza \\ ul. Ratajczaka 38/40, 60-967 Poznań, Poland
}

ABSTRACT. The article discusses the most important opinions of Bulgarian scholars on rich women burials in ancient Thracia. Analysis of subsequent sites, along with the newest archaeological discoveries (in particular, a burial from mound 47 at Smjadovo), makes possible to conclude that such burials really existed on the discussed territory, or at least on its part.

Początek dyskusji na powyższy temat sięga lat dwudziestych minionego stulecia. Wywołały ją właśnie wtedy rozpoczęte prace wykopaliskowe w miejscowości Duvanli, znajdującej się w odległości około $25 \mathrm{~km}$ na północ od miasta Płowdiw ${ }^{1}$. W stosunkowo krótkim okresie rozkopano tam szereg kurhanów ${ }^{2}$, z których na szczególną uwagę zasługują takie obiekty, jak: Kukuva Mogila ${ }^{3}$, Goljamata Mogila ${ }^{4}$, Bašova Mogila Lozarskata Mogila ${ }^{6}$, Arabadžijskata Mogila ${ }^{7}$ oraz Mušovica Mogila ${ }^{8}$.

' Chronologicznie niniejsze rozważania dotyczą przede wszystkim tak zwanej późnej epoki żelaza (jest to synonim drugiej połowy I tysiąclecia p.n.e.). Termin ten został calkowicie zaakceptowany i jest powszechnie stosowany w archeologii antycznej Tracji, co różni ten obszar zasadniczo pod względem nazewnictwa od przyjętego schematu dla centralnej Europy. Zdaniem większości badaczy raczej nie powinno się stosować obcych terminów, takich jak „okres lateński”, „okres hellenistyczny”. Pierwszy z nich bowiem nie ma żadnego związku z kulturą tracką, natomiast drugi może być wykorzystywany, ale tylko w odniesieniu do kultury centrów miejskich w Tracji (Domaradzki, Taneva 1998, s. 13-14).

${ }^{2}$ Przez określenie „kurhan” rozumiem sztuczny nasyp wykonany z samej tylko ziemi, z ziemi przemieszanej z kamieniami lub tylko z samych kamieni. Termin ten jest powszechnie stosowany w literaturze polskiej oraz w tłumaczeniach na język polski w odniesieniu do Traków oraz Scytów (tytułem przykładu: V e n e d i k ov, G e r a s i m ov 1978, s. 31 oraz K u b c zak 1978). W języku bułgarskim w tym przypadku używa się określenia „mogila”, a kiedy kurhan nie jest pusty i zawiera pochówek lub jakąś konstrukcję grobową stosuje się zwrot „,nadgrobna mogila”, w opozycji do terminu „žilištna mogila”, który oznacza sztuczne wzniesienie kryjące w sobie pozostałości po osadzie.

${ }^{3}$ D jak ovič $1925 ;$ F i l ov 1927; 1933, s. 273; 1934, s. 6-58; V enedikov, Gerasimov 1978, s. 31.

${ }^{4}$ Filov 1933, s. 218-247; 1934, s. 98-126; Venedikov, Gerasimov 1978 , s. 31.

${ }^{5}$ Velkov 1931, s. 1-25; Filov 1933, s. 274; 1934, s. 59-79; Ruseva 2002, s. 90 , nr 5.

${ }^{6}$ Filov 1933 , s. $248-252$.

${ }^{7}$ Filov 1933, s. $253-272 ; 1934$, s. $127-142$; Ruseva 2002 , s. 88 , nr 3.

${ }^{8}$ Velkov 1931, s. $25-42 ;$ Filov 1933, s. $273 ; 1934$, s. 82-97. 
Pod nasypami kurhanowymi tej nekropolii znajdowały się różnego rodzaju groby (oraz grobowce) $^{9}$. I tak w kurhanie Goljamata Mogila odkryto kamienny sarkofag. Konstrukcję tę wydatowano na połowę $\mathrm{V}$ w. p.n.e (a najpóźniej na pierwsze dziesięciolecia drugiej połowy V w. p.n.e. ${ }^{10}$ ). Również kamienny sarkofag krył w sobie kurhan Lozarskata Mogila. W kurhanie Bašova Mogila kamienne ściany grobu zostały przekryte drewnianymi belkami ${ }^{11}$. Inaczej wyglądało natomiast miejsce wiecznego spoczynku zmarłego człowieka w Arabadžijskata Mogila. Tutaj grób miał kształt dużej, czworokątnej jamy. W środku znajdowała się druga jama, w której złożono pochówek. W mniejszej jamie ściany zostały umocnione drewnianymi belkami, w ten sam sposób wykonano przekrycie. Chronologię ustalono na okres nie późniejszy jak koniec V w. p.n.e. ${ }^{12}$

Na podstawie inwentarza znalezionego w grobach koło Duvanli wysnuto przypuszczenie co do płci osób pochowanych w poszczególnych kurhanach. Nie udało się, niestety ustalić, czy kurhan Lozarskata Mogila zawiera szczątki mężczyzny, czy też może kobiety. Ponieważ jednak zwłoki poddano kremacji, a więc tylko tytułem analogii z innymi obiektami tej nekropolii, pochówek ten zinterpretowano jako żeński, a jego chronologie ustalono na okres nie późniejszy jak połowa V w. p.n.e. ${ }^{13}$ Natomiast za zdecydowanie żeński pochówek uznano szczątki ludzkie z kurhanu Arabadžijskata Mogila. Tutaj w grobie zorientowanym po linii: $\mathrm{E}$ - W znajdował się szkielet $\mathrm{w}$ pozycji wyprostowanej, z nogami lekko zgiętymi w kolanach i głową skierowaną na zachód. Na szkielecie oraz wokół niego znaleziono liczne ozdoby wykonane z metali szlachetnych. Powyżej piersi znajdował się złoty napierśnik o wadze $16,75 \mathrm{~g}$, długości $16,5 \mathrm{~cm}$ i szerokości 7,2 cm, a wokół szyi umiejscowiony był złoty naszyjnik. Po obu stronach głowy znaleziono natomiast złote kolczyki (po trzy z każdej strony głowy). Ponadto odkryto dwa kolczyki spiralne. Na jednym z palców lewej ręki tkwił złoty pierścień o wadze $14,80 \mathrm{~g}$, z podobizną jeźdźca oraz bardzo słabo czytelnym napisem. W grobie znajdowały się również naczynia ceramiczne oraz brązowe lustro o średnicy $15,3 \mathrm{~cm}$. Ogólna waga złotych przedmiotów należących do tego pochówku wynosiła $158,50 \mathrm{~g}^{14}$.

Kolejny obiekt w Duvanli, w którym dopatrywano się pochówku kobiety, to kurhan Kukuva Mogila. Konstrukcja grobowa znajdująca się pod nasypem została wykonana $\mathrm{z}$ obrobionego wapienia. Dno grobu wyłożono kamiennymi płytami $\mathrm{z}$ tego samego surowca. Inwentarz został częściowo rozgrabiony podczas eksploracji, zatem nie

\footnotetext{
${ }^{9} \mathrm{~W}$ starszej literaturze naukowej panuje calkowita dowolność w nazewnictwie poszczególnych obiektów grobowych, które przez jednych są nazywane grobami, a przez innych grobowcami. Niejednokrotnie ten sam autor stosuje oba terminy wymiennie i dlatego pisze o grobie, a kilka zdań dalej używa określenia grobowiec. Dokładniej na ten temat: R u s e v a 2002, s. 15. Autor niniejszego artykułu wyraża stanowisko, zgodnie z którym grobowiec to grób o konstrukcji wyraźnie przestrzennej.

${ }^{10} \mathrm{Fi} 1$ ov 1933, s. 275.

${ }^{1 /} \mathrm{V}$ e $1 \mathrm{k} \mathrm{ov} 1931$ s. 6 . Kurhan Bašova Mogila jest mlodszy o przynajmniej jedna generację od konstrukcji w kurhanie Goljamata Mogila (F i lov 1933, s. 275).

${ }^{12} \mathrm{~F}$ il ov 1933, s. 275

${ }^{13}$ Filov 1933, s. 275.

${ }^{14} \mathrm{Fil}$ ov 1933, s. 273.
} 
wiadomo, jaka jego część trafiła do muzeum. Z wyrobów ze złota, o ogólnym ciężarze $1270,10 \mathrm{~g}^{15}$, na szczególną uwage zasługuje płytka w kształcie ryby, długości $20 \mathrm{~cm}$, szerokości $8,3 \mathrm{~cm}$, grubości $0,5 \mathrm{~mm}$ i ciężarze $30,3 \mathrm{~g}$. Reprezentowane są też wyroby ze srebra, brązu, alabastru oraz gliny. Niektóre z wymienionych znalezisk sklasyfikowano jako kobiece przedmioty toaletowe. Pochówek w kurhanie Kukuva Mogila został w konsekwencji zinterpretowany jako żeński ${ }^{16}$, a jego datację ustala się ogólnie na $\mathrm{V}$ w. p.n.e. ${ }^{17}$ (a bardziej szczególowo na pierwsza połowę wieku $\mathrm{V}$ p.n.e. ${ }^{18}$ ).

Ostatnim interesującym nas obiektem $z$ nekropolii w Duvanli jest kurhan Mušovica Mogila. Prawdopodobnie pierwotnie szczątki ludzkie zostały tutaj złożone w drewnianej skrzyni, która z czasem zgniła i rozpadła się. Szkielet, niestety, nie zachował się w całości. Wyposażenie grobu było bogate, składało się ze złotych przedmiotów o ogólnym ciężarze $438,95 \mathrm{~g}^{19}$, z czego tylko sam napierśnik, długości $25,9 \mathrm{~cm}$ i grubości pośrodku $8,6 \mathrm{~cm}$, ważył $65,5 \mathrm{~g}^{20}$. Cennymi elementami były wykonane $\mathrm{z}$ tego samego kruszcu trzy fibule oraz brązowe lustro. Chronologię grobu ustalono na koniec VI lub początek V w. p.n.e. ${ }^{21}$

Bogatego pochówku kobiecego dopatrywano się także w pólnocno-zachodniej części Bułgarii, a mianowicie w kurhanie Mogilanskata Mogila, we Wracy ${ }^{22}$. Tutaj, pod prawdopodobnie pierwotnie istniejącą drewnianą konstrukcją grobową znaleziono obok szkieletu złoty wieniec ${ }^{23}$ oraz wykonane $z$ tego samego kruszcu kolczyki. Zarówno obok szkieletu, jak i pod nim, leżały także inne przedmioty, na przykład dwa żelazne noże, około 100 strzał z grotami z brązu z zachowanymi drzewcami itd. Przypuszczalnie strzały te umieszczone były pierwotnie $w$ kołczanie. Obok prawej nogi spoczywał wykonany z brązu hełm. W odległości około 1,5 m od szkieletu ustawiono luksusowe serwisy z pozłacanego srebra. W kurhanie z Wracy pochowano jeszcze

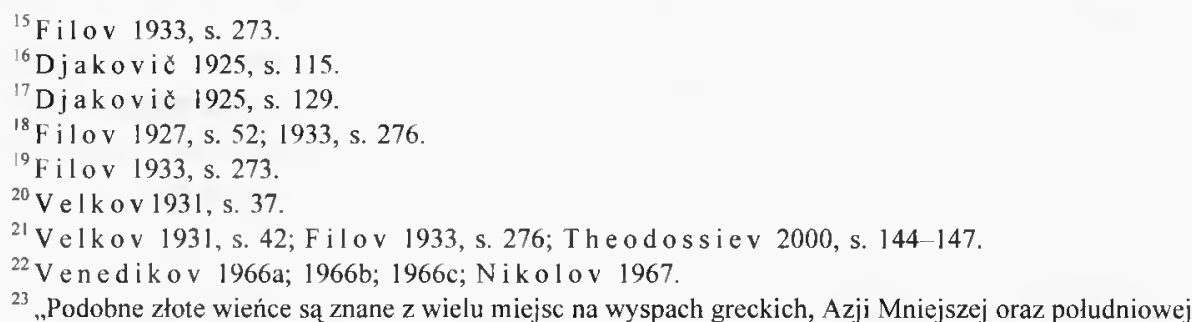
Rosji" (Venedikov 1966, s. 38), a takze z Verginy (Andronikos 1991, s. 17l-175). Z uwagi na trwajacy całe wieki proceder okradania grobowców trackich liczba znalezionych podobnych złotych wieńców nie jest duża. Na terytorium Bułgarii możemy odnotować dla przy kładu podobne znalezisko jeszcze z miejscowości Rozovec (Š k or p il 1898, s. 123-129; F il o v 1934, s. 158-171, 231: M a n s e 1 1943, s. 39; M i k o v 1955 , s. 21, 22). Ven edik ov (1966c, s. 38) wspomina o trzech takich znaleziskach. Natomiast nowe przykłady złotych wieńców pochodzą z europejskiej części Turcji. W Muzeum Archeologicznym w Tekirdağ eksponowany jest jeden taki wieniec. W okolicach Tekirdağ nad morzem Marmara rozkopano bowiem wspaniały obiekt, jakim jest niezwykle bogato wyposażony grób „królewski” (kurhan Harekâttepe). Jednak pozostałe materiały $z$ tego grobu zabrano obecnie do Ankary w celu ich przebadania i naukowego opracowania. W tym miejscu pragnę złożyć podziękowania na ręce pana Mehmeta Akifa Işına, dyrektora Muzeum Archeologicznego w mieście Tekirdağ, który udzielił mi wielu cennych informacji oraz zezwolił na zrobienie dokumentacji fotograficznej materiałów jeszcze niepublikowanych. 
jedną osobę, prawdopodobnie płci męskiej ${ }^{24}$. Przyjęto zatem, że miejsce to stanowiło „wieczne mieszkanie" rodziny władcy. Nie wiadomo jednak, czy oba pochówki - kobiecy i męski - są sobie współczesne, czy też występuje między nimi pewna różnica czasowa $^{25}$. Przyjąwszy pierwszy wariant można przypuszczać, że wzorem obyczajów opisanych w źródłach antycznych odnoszących się do Tracji, żona została złożona w ofierze po śmierci męża jako najcenniejsze votum, a obok jej ciała umieszczono wyposażenie grobowe zmarłego. W ten jedynie sposób można by wyjaśnić obecność przy ciele kobiety licznych przedmiotów uważanych powszechnie za atrybuty mężczyz$n y^{26}$. Ocenia się, że zmarła kobieta była dość niskiego wzrostu $(145-150 \mathrm{~cm})$, a dożyła około dwudziestu lat ${ }^{27}$.

Przedstawione poglądy o występowaniu bogatych pochówków kobiecych na obszarze antycznej Tracji funkcjonowały w nauce bułgarskiej przez kilkadziesiąt lat. Dopiero A. Fol stał się sprawcą swoistego fermentu naukowego w tej kwestii. W roku 1983 opublikował on mianowicie artykuł, zawierający zupełnie nowe spojrzenie na interesujący nas problem ${ }^{28}$. Badacz ten przypomniał rzecz wydawałoby się banalną, ale ogromnie ważną, iż o płci pochowanej osoby nie przesądza towarzyszący jej inwentarz grobowy. Fol podał w wątpliwość interpretację ,grobowców kobiecych" z nekropolii w Duvanli (w kurhanach Kukuva Mogila, Mušovica Mogila oraz Arabadžijskata Mogila) oraz z Wracy (kurhan Mogilanskata Mogila). Jego zdaniem nic nie przemawia za tym, aby u Traków urządzano z przepychem pochówki kobiece wraz z towarzyszącym im składaniem ofiar z koni oraz innych zwierząt. Badania archeologiczne, według opinii tego bułgarskiego badacza, w rzeczywistości jedynie w Tracji potwierdzają istnienie pochówków „królewskich” lub tak zwanych w literaturze przedmiotu „bogatych Traków”, czyli mężczyzn związanych z polityką, o różnych podstawach religijno-doktrynalnych. Zdaniem A. Fola to właśnie te przesłanki określają skład inwentarza grobowego i poprzez ich pryzmat należy oceniać przedmiotowe pochówki.

A. Fol podaje dodatkowo przykład z miejscowości Sveštari ${ }^{29}$, gdzie znaleziono luźno złoty kolczyk $\mathrm{z}$ wyobrażeniem głowy lwa. Tego typu luksusowe przedmioty, zdaniem A. Fola, nie muszą być wcale związane $\mathrm{z}$ pochówkiem żeńskim, ponieważ bogaty inwentarz sepulkralny może być równie dobrze przypisany królowi, który za życia nosił takie

${ }^{24}$ Jednakże w innej swojej publikacji Ivan V e n e di k ov (1966c, s. 37), powołując się na rzekome dane antropologiczne, napisał, iż oba szkielety należały do zmarłych kobiet. Pierwszy z nich należał do osobnika płci żeńskiej w wieku około 30 lat, a drugi do kobiety około dwudziestoletniej. $Z$ kolei $N$. T h e o d o s s i ev (2000, s. 145) uważa, iż mamy tutaj do czynienia ze szczątkami woźnicy lub poganiacza koni.

${ }^{25} \mathrm{Ni}$ k ol ov (1967, s. 12) opowiada się za kilkudziesięcioletnią różnicą czasowa.

${ }^{26}$ Venedikov 1966b, s. 12,13

${ }^{27}$ Nieco później N i k o l ov (1967) doszedł do wniosku, iż w kurhanie Mogilanskata Mogila mamy w rzeczywistości do czynienia z trzema grobami. Natomiast T h e o d o s s i e v (2000, s. 146) przypuszcza, że znaleziony szkielet osobnika niskiego wzrostu należal prawdopodobnie do syna króla Tryballów lub nawet, być może, do dziedzica korony (s. 146). Natomiast sam kurhan Mogilanskata Mogila, zdaniem tego badacza, zostal usypany w trzech fazach, w ciagu około 50-70 lat (s. 145).

${ }^{28} \mathrm{Fol} 1983$.

${ }^{29}$ Čičikova $1983 ; 1986 ; 1988 ; 1989 ;$ Enev, Krăstev 1986. 
ozdoby, zmienne w zależności od charakteru oficjalnej ceremonii czy święta lub przy okazji składania ofiar ${ }^{30}$.

Konstrukcja grobowa w Sveštari koresponduje $\mathrm{z}$ trzema innymi grobowcami ${ }^{31}$ tak zwanego macedońskiego typu z nekropolii w Sborjanovo, gdzie przekrycie komory grobowej i przedsionka (a w przypadku Sveštari także i komory bocznej) jest kolebkowe. Do tej pory grobowiec ze Sveštari jest zdecydowanie najcenniejszym tego typu obiektem w Bułgarii ${ }^{32}$. A. Fol zwraca uwage na istnienie w tym grobowcu malowidła przedstawiającego Boginię-Matkę, która trzyma w wyciągniętej ręce wieniec $\mathrm{i}$ kieruje go w stronę głowy osoby siedzącej na koniu, co interpretuje się jako akt koronacji, a na poziomie religijno-doktrynalnym jako inwestyturę dokonywaną przez Boginię-Matkę.

Analizując ozdoby towarzyszące pochówkom uznawanym powszechnie za kobiece (w szerszym kontekście) A. Fol doszedł do wniosku, iż wszystkie one mogą stanowić elementy specjalnego stroju rytualnego „króla”, podkreślające religijno-doktrynalny charakter jego władzy. Tym samym można dokonać reinterpretacji 10 złotych kolczyków z „kobiecego” pochówku w kurhanie Mušovica Mogila, a także tego samego rodzaju ozdób znalezionych w „kobiecym” pochówku w kurhanie Arabadžijskata Mogila. A. Fol przypuszcza, że szkielet „kobiecy” w kurhanie Mogilanskata Mogila w rzeczywistości jest szkieletem młodego mężczyzny, następcy tronu (księcia), ponieważ obok głowy zmarłego położono obrzędowy nagolennik z wyobrażeniem Wielkiej Bogini-Matki. Także inne przedmioty znalezione w pochówkach „,kobiecych”, powszechnie wiazane $\mathrm{z}$ wyposażeniem bogatych dam, według opinii bułgarskiego badacza dadzą się inaczej zinterpretować. W kurhanach Arabadžijskata Mogila, w Mušovica Mogila (a nie są to jedyne znane przypadki) znaleziono lustra. A. Fol twierdzi, że lustro mogło być atrybutem królewskim w określonej sytuacji obrzędowej. Podobnie przedstawia się problem brązowego amuletu z „kobiecego” pochówku w kurhanie Arabadžijskata Mogila, z którego kształtu wnioskuje się, że jest derywatem - „obuwiem” w kształcie lwa. Z pomocą przychodzą tutaj dane porównawcze; znana jest bowiem stara tradycja anatolijska dotycząca noszenia tego typu obuwia podczas pewnych ceremonii religijnych, która objaśnia znaczenie tego amuletu.

Wobec powyższych uwag należy stwierdzić, że A. Fol zanegował istnienie w Tracji bogatych pochówków kobiecych.

W roku 1994 ponownej interpretacji interesującego nas zagadnienia podjęła się bułgarska badaczka M. Tačeva ${ }^{33}$. Rozpoczęła ona studia od analizy historycznej epoki,

${ }^{30}$ Ten punkt widzenia zdają się też potwierdzać wykopaliska w okolicach Seuthopolis, gdzie prawie w każdym grobie znaleziono ozdoby (najwięcej kolczyków), niezależnie od tego, czy grób kryl w sobie szczątki mężczy zny, czy kobiety oraz niezależnie od tego czy był to obrządek szkieletowy, czy ciałopalny ( $L$ i l o v a 1991, s. 52).

${ }^{31} \mathrm{Saq}$ to grobowce o numeracji: 12, 13 oraz 30 (ostatni $z$ nich nie jest jeszcze opublikowany).

${ }^{32}$ Pozostałe trzy grobowce: Sborjanovo 12 (G e r g o va 1996, s. 13-44; R u s e v a 2000, s. 15I-154); Sborjanovo 13 (G e rg ov a 1996, s. 13 44; R u s e v a 2000, s. 146-150) oraz Sborjanovo 30 (jeszcze niepublikowany) oraz kilka podobnych obiektów z obszaru Bułgarii, a także z europejskiej części Turcji jest nieco skromniej wykonanych.

${ }^{33} \mathrm{~T}$ a č ev a 1994. Autorka ta przypomniała, iż prof. B. Filov pozostawil otwartą kwestię, kto został pogrzebany w kurhanach koło Duvanli. 


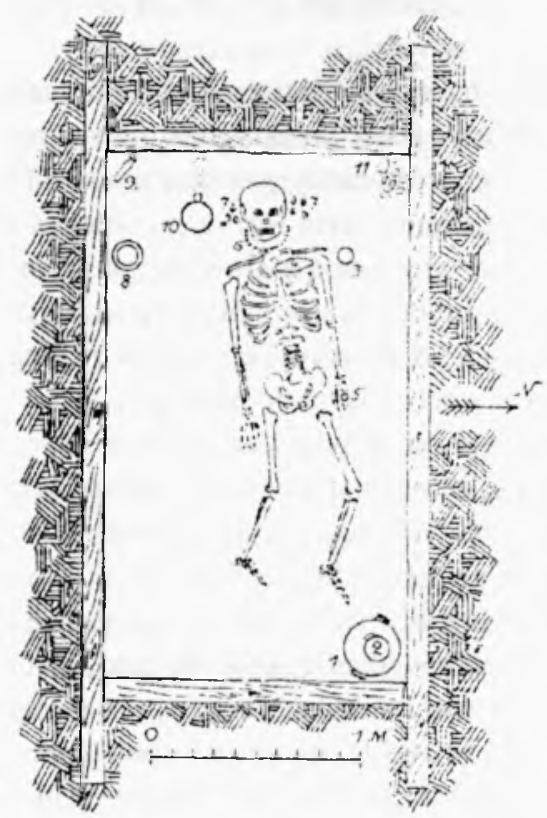

Ryc. 1. Rzut poziomy grobu w Arabadžijskata Mogila (wg Filov 1933)

Abb. 1 Grundriß des Grabes Arabadžijskata Mogila (nach Filov 1933)

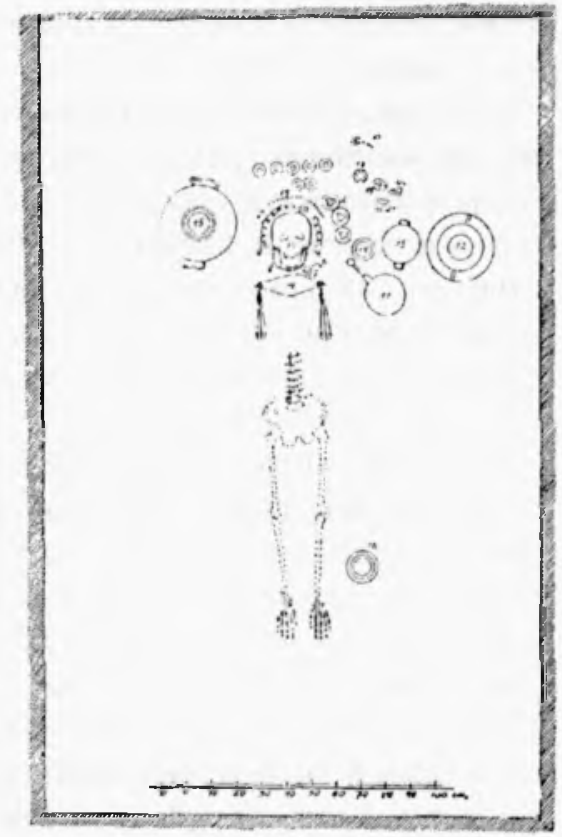

Ryc. 2. Rzut poziomy grobu w Mušovica Mogila (wg Velkov 1931)

Abb. 2 Grundriß des Grabes Mušovica Mogila (nach Velkov 1931)

z której pochodza bogate pochówki wiązane prawdopodobnie z kobietami. Przypomniała wyprawy królów perskich Dariusza I i Kserksesa w VI-V w. p.n.e. W czasie kampanii scytyjskiej w 513 r. p.n.e. strona perska dążyła bez powodzenia do konfrontacji militarnej z Odrysami, wkraczając na ich ziemie z niemałym oddziałem. Odrysi pod wodzą swego króla Teresa nie uważali jednak za korzystne atakowanie Persów na obszarach przez nich rządzonych. Tym właśnie, zdaniem M. Tačevej, można wyjaśnić nieobecność Odrysów wśród wspomnianych przez Herodota sojuszników wasalnych i poddanych królów perskich do 480 r. p.n.e. Wskazując na powiązania odrysko-perskie bułgarska badaczka wiąże pochówek z kurhanu Mušovica Mogiła z osobą bogatej i rodowitej perskiej żony wladcy trackiego Teresa. Natomiast pochówki z kurhanów Goljamata Mogila i Bašova Mogila, zgodnie z badaniami wyżej wymienionej autorki nad inwentarzem grobowym i semantyką wyobrażeń na czerwonofigurowych naczyniach attyckich, dowodzą, że spoczywający tam zmarli to władcy odryscy: Sparadokos oraz Seuthes I. Dalej już M. Tačeva argumentuje w czterech zasadniczych punktach swoje stanowisko, odwołując się między innymi do danych onomastycznych.

Przedstawione w pierwszej części artykułu dwie hipotezy odnośnie do interpretacji bogatych pochówków z Duvanli oraz jednego z Wracy egzystują nadal w trakologii, 


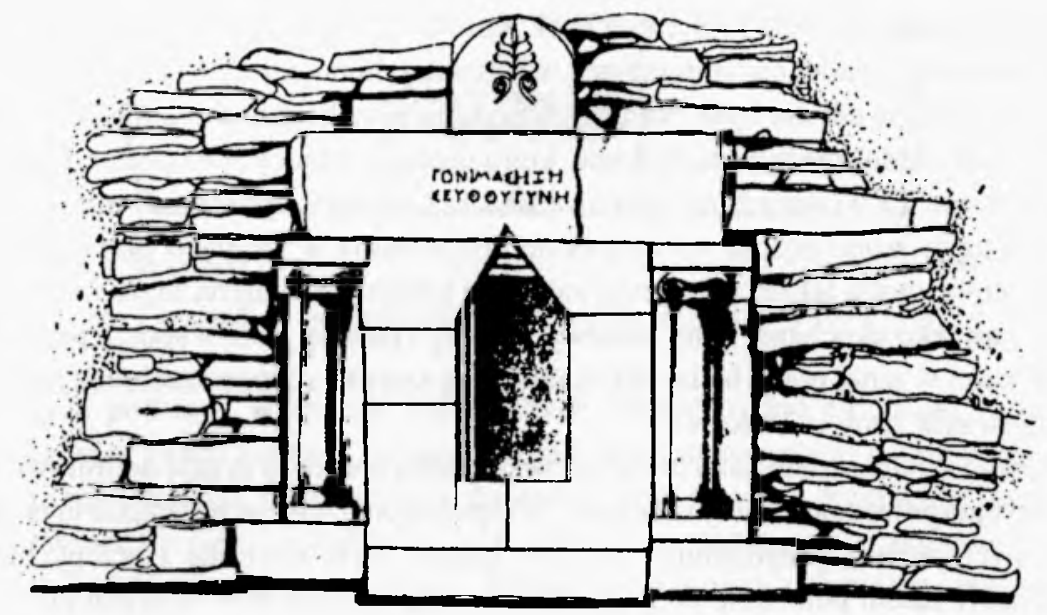

Ryc. 3. Grobowiec w miejscowości Smjadovo (wg Atan as ov 2002).

Abb. 3 Grabkammer von Smjadovo (nach Atan os ov 2002)

a końca rozwiązania kwestii nie widać. Dlatego też w zależności od jednej z dwóch teorii, ku której skłania się dany badacz, interpretuje się kolejne znaleziska. Przykładem może służyć stanowisko Kralevo, gdzie w kurhanie nr 1 znajdują się dwa grobowce obok siebie. W jednym z nich ( $\mathrm{nr}$ 2), zdaniem G. Gineva, pochowano mężczyznę o wyjątkowym statusie społecznym - wysokiej rangi dowódcę wojskowego. Natomiast pozostaje zagadką, kto spoczywa w grobowcu obok, może żona zmarłego? Takiej możliwości nie wyklucza się. Jednak G. Ginev, odwołując się do poglądów A. Fola twierdzi, że jeśli ten badacz ma rację, to należałoby w grobowcu nr 1 upatrywać raczej szczątków mężczyzny - innego „,bogatego Traka”, być może krewnego (syna lub brata?), a nie kobiety ${ }^{34}$.

Na temat kobiety trackiej wiemy jeszcze stosunkowo niewiele. Przekazy autorów antycznych, odnoszące się do życia kobiet oraz stosunków rodzinnych na obszarze antycznej Tracji są dalekie od danych dotyczących innych obszarów (np. Grecji czy Rzymu). Dlatego też literatura naukowa poruszająca tę problematykę jest niezwykle skromna ${ }^{35}$. Ostatnio tematem tym zajęła się D. Kotova. W jednym ze swoich artykułów dokonała zestawienia najważniejszych źródeł antycznych dotyczących pozycji kobiety w trackich społecznościach plemiennych ${ }^{36}$. Z jej badań wynika, że poligamia u Traków, a przynajmniej u Odrysów, stanowila realność minimum do roku 400 p.n.e. ${ }^{37}$ Dziwne, że źródła dotyczące dynastów lub paradynastów ${ }^{38}$ trackich wspominają tylko jedną żonę, co jest

${ }^{34} \mathrm{G}$ inev 2002, s. 40.

${ }^{5}$ Dla przykładu: Ven edik ov 1977.

${ }^{36} \mathrm{~K}$ ot ova 1988.

${ }^{37}$ Kotova 1988 , s. 66.

${ }^{38}$ Nazwą paradynastów określa się wladców pomniejszych i slabszych plemion trackich, którzy byli podporządkowani znacznie od nich potężniejszym sąsiadom (V en e dik ov 1966 c, s. 38). 
w jawnej opozycji do stanu faktycznego. D. Kotova zastanawia sie zatem, czy mamy tutaj do czynienia z tendencją zmierzającą w kierunku monogamii? Ostatecznie dochodzi ona do wniosku, iż tak nie było. Najprawdopodobniej tylko jedna z żon miała specjalny status. Prawdopodobnie była nią kobieta, która urodziła władcy syna przeznaczonego na następcę tronu. Ta właśnie żona była uważana za główną i reprezentatywną żonę i jako matka następcy tronu została sporadycznie odnotowana w źródłach pisanych.

D. Kotova uważa także, że obyczaj zabijania kobiety po śmierci męża i chowania jej razem $\mathrm{z}$ nim jako ukochanej żony stanowił swoisty rytualny teatr w sporze prestiżowym $\dot{z ̇ o n}^{39}$. Z kolei w innej pracy badaczka ta zajęła się szeroko rozpowszechnionym obyczajem kupowania żony u Traków ${ }^{40}$.

Zarówno źródla pisane, jak i literatura przedmiotu nie rozstrzygają definitywnie, jaka byla pozycja społeczna kobiety u Traków. Nie pomaga to więc w rozwiązaniu problemu, czy po swej śmierci, przynajmniej niektóre kobiety były chowane z przepychem.

Wracamy zatem ponownie do poglądów A. Fola. Prowadzone od wielu lat systematyczne prace wykopaliskowe na terenach zamieszkałych w starożytności przez Traków ujawniają od czasu do czasu bogate i nieograbione pochówki. Bardzo szkoda, że nie przeprowadza się badań antropologicznych, które pomogłyby rozstrzygnąć spór o płeć pochowanych $w$ danym obiekcie osób ${ }^{4 !}$. Przecież w wielu przypadkach szkielety zachowaly się w bardzo dobrym stanie. Nie wdraża się też, niestety, badań DNA, które dałyby wiarygodne dane co do pokrewieństwa poszczególnych zmarlych osób. W przypadkach, gdy bogaty pochówek zawiera przedmioty przypisywane powszechnie i mężczyźnie, i kobiecie, to we wnioskowaniu opartym tylko na tym inwentarzu występują duże trudności w interpretacji plci osoby pochowancj w danym grobie czy grobowcu.

W ostatnim czasic jako kobiecy interpretuje się pochówek z kurhanu nr IX na nekropoli Devette Mogili koło Seuthopolis, gdzie wśród inwentarza grobowego znaleziono między innymi pozłacany wieniec datowany na IV w. p.n.e. ${ }^{42}$, a także srebrne fibule oraz ozdoby $^{4 i}$. Z kolei pochówek z kurhanu Malkata Mogila, znajdującego się także w Dolinie Kazanłyckiej, został uznany za miejsce wiecznego spoczynku króla-kapłana. Także i tutaj odnotowano złote ozdoby, lecz o zakwalifikowaniu pochówku jako męskiego zadecydowała przede wszystkim podwójna siekiera - symbol władzy ${ }^{44}$. Jak zatem widać, interpretacja poszczególnych znalezisk nie jest pewna. Brązowe lustra są spotykane również w pochówkach, co do których z dużą dozą prawdopodobieństwa możemy przyjąć, że zmarła osoba była płci męskiej. W związku z tym, za całkowicie zasadny postulat A. Fola uważam ten podający w wątpliwość klasyfikację kilku pochówków uznanych w przeszłości za pochówki kobiece. Uznanie ich za pochówki męskie też jednak nie

\footnotetext{
${ }^{39} \mathrm{Kotova} 1988$, s. 68 .

${ }^{40}$ Kotova 2001 .

${ }^{4 \mid}$ Sporadycznie przeprowadza się tylko analizę zwierzęcego materialu kostnego ( $\mathrm{N}$ in o v 1996 ).

${ }^{42}$ W okolicach Seuthopolis w siedmiu pochówkach znajdujących się w kurhanach znaleziono aż dziewięć wieńców fragmentarycznie zachowanych, będących symbolem nieśmiertelności (1 i l o v a 1991, s. 52). Nie zostały one jednak wykonane ze złota, a tylko z brązu poktytego cienką warstwą złota.

${ }^{47}$ I. ilova 1991; Dolinata na rozite, 2001, s. 163, 164, 166.

${ }^{44} \mathrm{~K}$ it ov 1994, s. 86; Dolinata na rozite, 2001, s. 161, 162.
} 


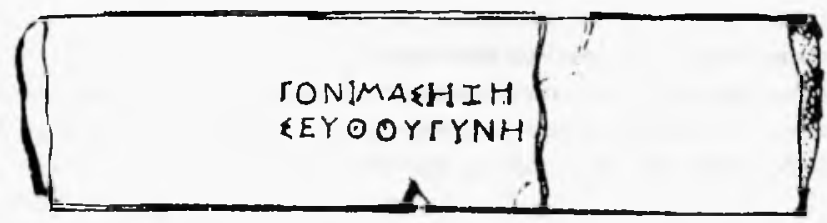

Ryc. 4. Inskrypcja na grobowcu z miejscowości Smjadovo (wg A tan as ov 2002).

Abb. 4 Inschrift an der Grabkammer von Smjadovo (nach At a n o sov 2002)

ma mocnych podstaw. W świetle najnowszych odkryć trudno natomiast zgodzić się z jego teza, iż w Tracji nie było zwyczaju urządzania z przepychem pochówków kobiecych. Najlepszym tego przykladem i dowodem jest bowiem przepiękny grobowiec z miejscowości Smjadovo (kurhan nr 47), obecnie eksponowany w regionalnym muzeum historycznym w mieście Szumen ${ }^{45}$. Został on wykonany z kamienia i posiadal dwa pomieszczenia. Najważniejszym jednak dla nas jego elementem jest wyryta na grobowcu inskrypcja z imieniem bogatej damy o imieniu Gonimasedze. Wiadomo zatem ponad wszelką wątpliwość, że pochowana tutaj osoba to kobieta. Niestety, inwentarz grobowca został zrabowany i nie może wspierać niniejszych rozważań, sama tylko konstrukcja grobowa świadczy o przepychu, z jakim złożono tutaj na wieczny spoczynek zmarłą kobietę.

Na postawione pytanie, czy w Tracji istnialy bogate pochówki kobiece, należy odpowiedzieć twierdząco. Jest bowiem prawdopodobne, a w każdym razie nie można wykluczyć, iż przynajmniej niektóre analizowane wyżej bogate pochówki trackie były rzeczywiście kobiecymi. Natomiast niezbitym dowodem istnienia grobowca kobiecego jest konstrukcja sepulkralna z miejscowości Smjadovo ${ }^{46}$. Niestety, co do ich liczby oraz dyslokacji brakuje na obecnym etapie badań konkretnych informacji, zwłaszcza z uwagi na absencję danych antropologicznych. Nie możemy też twierdzić, że bogate pochówki kobiece w Tracji były powszechnością, jednak ich występowanie tu i ówdzie jest faktem.

\section{BIBLIOGRAFIA}

Andronikos V.

1991 Vergina: the Royal Tombs and the Ancient City, Athens. Atanasov G.

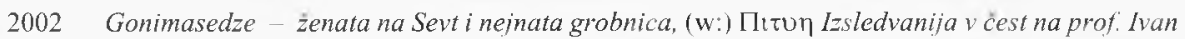
Marazov [Studia in honorem Prof. Ivani Marazov], Sofija, s. 550-557.

Ċičikova $\mathrm{M}$.

1983 Grobnicata ot Sveštari, „Izkustvo" b. 3, s. 18-27.

1986 Trakijskata grobnica pri Svestari, „Dariteli” cे. 1-2, s. 10-15.

${ }^{45}$ Atanasov 2002.

${ }^{46}$ Georgi Atanasov zakłada, że żony osób wysoko postawionych w hierarchii społecznej posiadahy oddzielne grobowce w przypadku, kiedy umierały wcześniej od swych męzów (A t a n a s o v 2002, s. 554). 
1988 Sveštarskata grobnica - architektura i dekoracija [Sum.: The Svestari tomb - architecture and decoration], „Тепra Antiqua Balcanica” t. 3, s. 125-143.

1989 Tombeau royal de Sveštari et certains aspects du culte sépulcral thrace, (w:) Thracians and Mycenaeans. Proceedings of the Fourth International Congress of Thracology, Rotterdam, 24-26 September 1984, Leiden - Sofia, s. 205-217.

Djakovič B.

1925 Antična grobnica v „Kukuva mogila” pri s. Duvanlij, Plovdivsko [Rés.: Un tombeau antique à „Koukouva Moghila” près du village de Douvanly, district de Plovdiv], „Izvestija na Archeologičeskija Institut" 3, s. 111-130.

Dolinata na rozite

2001 Dolinata na rozite itrakijskite vladeteli [Sum.: The valley of Roses and Thracian Rulers], Plovdiv.

Domaradzki M., Taneva V.

1998 Trakijskata kultura v prechoda kăm elinističeskata epocha (= Emporion Pistiros. T. 2) Septemvri.

Enev M., Krăstev K.

1986 Trakijskata grobnica ot Sveštari [Sum.: The thracian tomb at Sveshtari]. Fotoizložba v Nacionalnija istoričeski muzej Sofija, Sofija.

Filov B

1927 Novi nachodki ot antičnata grobnica pri Duvanlij [Zus.: Neue Funde aus dem antiken Hügelgrabe bei Duvanli], ,Izvestija na Archeologičeskija Institut” 4, s. 27-60.

1933 Novootkriti trakijski grobnici ot Duvanlij [Zus.: Neuentdeckte thrakische Hügelgräber von Duvanli (Südbulgarien)], „Izvestija na Archeologičeskija Institut” 7, s. 217-280.

1934 Nadgrobnite mogili pri Duvanlij v Plovdivsko, Sofija.

Fol A.

1983 Vtora godina „Getika”, ,Izkustvo” 3, s. 3-5.

Gergova D.

1996 Obredăt na obezsmărtjavaneto v drevna Trakija [Sum.: The rite of the immortalization and the tumuli in Sveshtari], Sofija.

Gine $v$ G.

2002 Mogila I ot nekropola pri Kralevo, Tărgovisttko [Sum.: Mound I from the Necropolis near Kralevo, Turgovishte Region], „Archeologija” g. 43, kn. 1, s. 32-42.

Kitov G.

1994 Trakijski mogili v hinterlanda na Sevtopolis [Rés.: Tombeaux thraces dans I'hinterland de Sevtopolis], (w:) Poselisten život v drevna Trakija. III meżdunaraden simpozium „Kabile”. 17-21 maj 1993, Jambol, s. 85-90.

Kotova D.

1988 Trakijskite ženi, (w:) Jubilaeus I D. Dečev. Jubileen sbornik v pamet na akad. Dimităr Dečev, Sofija, s. 66-68.

2001 Bračnijat otkup pri Trakite, „Seminarium Thracicum” 5, s. 91-100.

$\mathrm{Kubczak} \mathbf{J}$.

1978 Kurhany anystokracji scytyjskiej [Sum.: Barrows of the Scythian Aristocracy], Poznan.

Lilova $B$

1991 Pogrebalni običai prez elinističeskata epocha v rajona na Sevtopolis [Sum.: Burial rites in the region of Seuthopolis during the Hellenistic Age], (w:) Sbornik trakijskata kultura prez eliniceskata epocha v Kazanlăškija kraj, Kazanlăk, s. 47-59.

1994: Nadgrobnite mogili v Kazanlăško [Sum.: Burial Tumuli in the Kazanluk Region], (w:) Părvi meždunaroden simpozium ".Sevtopolis". ", Nadgrobnite mogili v jugostočna Evropa", Veliko Tărnovo [Sum.: First International Symposium 'Seuthopolis'. Burial Tumuli in the South East of Europe], Veliko Tărnovo, s. 117-129. 
Mansel A.M.

1943 Trakya kirklareli kubbeli merazlari ve sahte kubbe ve kemmer problemi [Zus.: Die Kuppelgräber von Kirklareli in Thrakien und das Problem der "falschen» Kuppeln und Gewölbe], Ankara.

Mikov V.

1955 Proizhodăt na kupolnite grobnici v Trakija [Proischoždenie kupol'nych grobnic vo Frakii], „Izvestija na Archeologičeskija Institut”, t. 19 (Sbornik Gavril Kacarov, cast II), s. 15-48.

Nikolov B.

1967 Grobnica III ot Mogilanskata mogila văv Vraca, „Archeologija” kn. 1, s. 11-18.

Ninov L.

1996 Životinskite kosti ot dve trakijski grobnici v Kazanlaškata kotlovina - Sašova i Slavčova mogili

[Rés.: Les os d'animaux de deux tombes dans la valleé de Kazanlăk: Sas̄ova mogila et Slavčova mogila], ,Archeologija” kn. 2-3, s. 23-30.

Ruseva $M$.

2002 Trakijska grobična architektura v bălgarskite zemi prez $V-$ III v. pr.n.e., Jambol.

Škorpil Ch. I K.

1898 Mogili, Plovdiv.

Tačeva M.

1994 Nadgrobnite mogili pri Duvanlij v Plovdivsko - rodov nekropol na Odriskata dinastija na Teres (5.-4. v) [Sum.: The funeral mounds near Duvanli (district of Plovdiv): a hereditary burial-ground of king Terez's Odrisi dynasty $\left(5^{\text {th }}-4^{\text {th }}\right.$ C.B.C.), (w:) Părvi meždunaroden simpozium "Sevtopolis". ,Nadgrobnite mogili vjugostočna Evropa" [First International Symposium "Seuthopolis'. Burial Tumuli in the South East of Europe], Veliko Tărnovo, s. 145-148.

Theodossiev N.

2000 North-Western Thrace from the Fifth to First Centuries BC, „British Archaeological Reports, International Series" s. 859.

Velkov I.

1931 Mogilni grobni nachodki ot Duvanlij [Zus.: Grabhügelfunde aus Duvanli in Südbulgarien],

Venedikov I.

„Izvestija na Archeologičeskija Institut” 6, s. 1-44.

1966a Le tumulus de Vraca, „Etudes Balkaniques” 5, 1966, s. 243-248.

1966b Novootkrito trakijsko mogilno pogrebenie văv Vraca, „Archeologija” kn. 1, s. 7-15.

$1966 \mathrm{c}$ Novgoljam izvor za proučvane na trakijskoto izkustvo, „Izkustvo” 16, b. 2, s. 37-42.

1977 La condition de la femme en Thrace Antique, „Thracia” 4, s. 165-175.

Venedikov I., Gerasimov T.

1976 Sztuka tracka, cz. 1, Warszawa.

1978 Sztuka tracka, cz. 2, Warszawa.

\section{DIE FRAGE DER REICHEN FRAUENGRÄBER IM ANTIKEN THRAKIEN}

\section{Zusammenfassung}

Die Diskussion über die reichen Frauengräber setzte in den zwanziger Jahren des vergangenen Jahrhunderts ein. Sie wurden in jener Zeit durch Ausgrabungen in der Ortschaft Duvanli, etwa $25 \mathrm{~km}$ nördlich von Plovdiv, in Gang gesetzt. Innerhalb eines verhältnismäßig kurzen Zeitraumes wurde hier eine Reihe von Grabhügeln untersucht. Die menschlichen Überreste der Grabhügel Arabidžiskata Mogila, Kukuva Mogila und Mušsovica Mogila wurden damals als weibliche Bestattungen interpretiert. Jahrzehnte später wurden sehr wichtige Entdeckungen im nordwestlichen Teil Bulgariens gemacht, vor allem im Grabhügel Mogilanskata Mogila in Vraca. Unter der Hügelaufschüttung fand man drei Gräber, von denen mindestens eines als Frauenbestattung gedeutet wurde. 
Einen völlig anderen Standpunkt zum Geschlecht der in den oben genannten Anlagen beigesetzten Personen vertrat A. Fol. Im Jahre 1983 erinnerte dieser Forscher daran, daß die begleitenden Grabinventare nichts über das Geschlecht aussagen. Er zog daher die Interpretation von „reichen Frauengräbern” auf den Nekropolen von Duvanli und Vraca in Zweifel. Seiner Meinung nach deutet nichts daraufhin, daß bei den Thrakern prunkhafte Frauenbestattungen mit sie begleitenden Pferdeopfern oder Opfern von anderen Tieren üblich waren. Die archäologischen Forschungen zeigen nach Ansicht des buigarischen Forschers einzig die Existenz von „,königlichen" Grablegen in Thrakien bzw. der in der Fachliteratur sogenannten „reichen Thraker”, also mit Politik auf verschiedener religiös-herrschaftlicher Grundlage verbundener Männer. Diese und keine anderen Gründe führen zur Zusammensetzung der Grabinventare und durch ihr Prisma müsse man die Bestattungen sehen.

Im Jahre 1994 wurde erneut ein Deutungsversuch zum hier interessierenden Problem von der bulgarischen Forscherin M. Tačeva vorgenommen. Ihrer Meinung nach müsse man die Bestattung im Hügel Mušovica Mogila mit der Person der reichen Ehefrau persischer Abstammung des thrakischen Fürsten Teres verbinden. Und so bestehen ab diesem Moment in der Thrakienforschung zwei sich gegenüberstehende Hypothesen. Die erste geht von der Existenz reicher Frauenbestattungen aus, die zweite lehnt dies völlig ab.

Die Diskussion hätte man längst mit Erfolg beenden können, wären anthropologische Untersuchungen durchgeführt worden, denn die Skelette (wenigstens im Falle einiger uns interessierender Gräber) sind gut erhalten.

Ein neues Licht auf das Problem warf in der letzten Zeit eine Sepulkralkostruktion in der Ortschaft Smjadovo. Dank einer Inschrift an der Grabkammer besteht kein Zweifel, daß hier eine Frau bestattet wurde.

Die Frage, ob in Thrakien reiche Frauengräber angelegt wurden, muß bejaht werden. Es ist zudem wahrscheinlich, auf jeden Fall aber nicht auszuschließen, daß wenigstens einige reiche thrakische Bestattete Frauen waren. Ein unschlagbarer Beweis ist die Existenz der Grabkammer von Smjadovo. Leider fehlen aufgrund ihrer Zahl und ihrer Dislozierung zum gegenwärtigen Zeitpunkt konkrete Informationen, vor allem wegen der ausbleibenden anthropologischen Daten. Wir können nicht annehmen, daß reiche Frauenbestattungen in Thrakien allgemein waren, jedoch ist ihr Auftreten hier und dort ein Fakt. 